University of Rhode Island

DigitalCommons@URI

The Rhode Island Current Conditions Index

Economics

$12-2003$

\title{
Rhode Island Current Conditions Index - December 2003
}

Leonard Lardaro

University of Rhode Island, lardaro@uri.edu

Follow this and additional works at: https://digitalcommons.uri.edu/ricci

Part of the Econometrics Commons

Terms of Use

All rights reserved under copyright.

\section{Recommended Citation}

Lardaro, Leonard, "Rhode Island Current Conditions Index -- December 2003" (2003). The Rhode Island Current Conditions Index. Paper 131.

https://digitalcommons.uri.edu/ricci/131

This Article is brought to you for free and open access by the Economics at DigitalCommons@URI. It has been accepted for inclusion in The Rhode Island Current Conditions Index by an authorized administrator of DigitalCommons@URI.For more information, please contact digitalcommons-group@uri.edu. 


\section{Current Conditions I ndex \\ LEONARD LARDARO URI}

Also available online: http:/ / members.cox.net/ lardaro/ current.htm

Volume X, Number 2

December 2003

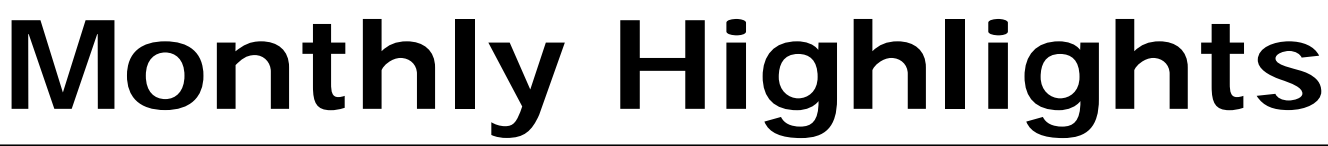

Rhode Island's fourth quarter ended on a high note, even though the December Current Conditions Index fell from November's value of 83 back to 67. In December, eight of the twelve $\mathrm{CCl}$ indicators improved. Perhaps more importantly, none of the indicators that failed to improve reflected substantial weakness. In fact, one indicator, Help Wanted, didn't fall at all, but it didn't increase either.

For all of 2003, the $\mathrm{CCl}$ exceeded its year-earlier value for every month since May. Thus, May was the turning (actually inflection) point for Rhode Island's economy, as it convincingly fought off the possibility of a double dip recession in the first quarter. The biggest surprise, though, continues to be Manufacturing Man-hours, which has now risen for the last two months. That hasn't happened since early 2001 .

\begin{tabular}{lr}
\multicolumn{2}{c}{ CCI Indicators - \% Change } \\
Government Employment & -0.8 \\
US Consumer Sentiment & $6.8 \mathrm{Y}$ \\
Single-Unit Permits & -1.4 \\
Retail Sales & $1.9 \mathrm{Y}$ \\
Help Wanted Advertising & 0.0 \\
Priv. Serv-Prod Employment & $0.7 \mathrm{Y}$ \\
Man-Hours Manufacturing & $1.0 \mathrm{Y}$ \\
Manufacturing Wage & $0.7 \mathbf{Y}$ \\
Labor Force & $0.2 \mathrm{Y}$ \\
Benefit Exhaustions & $-0.1 \mathrm{Y}$ \\
New Claims & 2.8 \\
Unemployment Rate & $-9.1 \mathbf{Y}$
\end{tabular}

Y = I mproved Value

Retail Sales, which has been a stellar performer throughout this recovery, grew for the eleventh time in the past twelve months (although there are measurement problems at present with this statistic), assisted by rising US Consumer Sentiment $(+6.8 \%)$ that continues to sustain its recent string of values above 90 . The improving stock market and less bleak job prospects appear to be moving Sentiment above the weak values it experienced earlier. Volatility in new home construction continued in December, as Single-Unit Permits fell by 1.4 percent compared to last December, moving below a 2,000 unit annual rate. Weather is likely to be an important contributing factor to this apparent weakness.

Weakness in labor demand continues to diminish. Help Wanted Advertising remained constant in December, a welcome change after a long string of double-digit declines. New Claims for Unemployment Insurance, the most timely measure of layoffs, rose by 2.8 percent in December, but this is only the second time in the last ten months that this indicator has failed to improve. At the same time, long-term unemployment, as measured by Benefit Exhaustions, fell by 0.1 percent, remaining well below a 20,000 annual rate. Finally, Rhode Island's Unemployment Rate, 5 percent, was higher than November's 4.9 percent rate, but well below its value last December (of 5.5\%) and less than the national rate.

Rhode Island's manufacturing labor market improved once again in December as Manufacturing Man-hours rose by $1.0 \%$, posting its second consecutive improvement when comparing to year-earlier values and the third improvement on a month-to-month basis. The Manufacturing Wage increased $(+0.7 \%)$, although wage growth appears to be stuck at around a one-percent annual rate. Private Service-Producing Employment grew more slowly in December $(+0.7)$, continuing a weak stretch that began in April (although I expect this to be revised away). Finally, ongoing budget difficulties resulted in yet another decline in Government Employment $(-0.8 \%)$, a continuation of the downside of efforts taken to balance state and local budgets.

Rhode Island's economic performance for the fourth quarter and 2003 overall was very encouraging. The upcoming labor market data revisions should be very telling. I expect the lowest of unemployment rates in 2003 (September and October) to be revised higher, and payroll employment growth to increase from the levels currently reported. Not a great outcome, but good enough for now.

\section{Current Conditions I ndex}

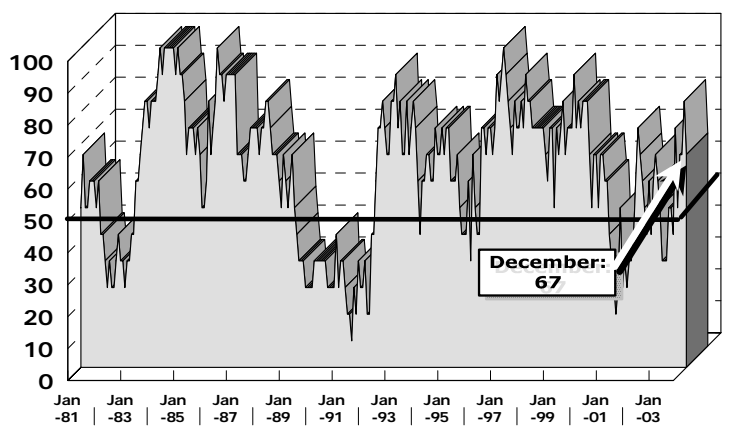

\begin{tabular}{|c|c|c|c|c|c|c|c|c|c|c|c|c|}
\hline & J an & Feb & Mar & Apr & May & J un & J ul & Aug & Sep & Oct & Nov & Dec \\
\hline 2002 & 58 & 75 & 67 & 58 & 42 & 33 & 50 & 42 & 50 & 58 & 50 & 50 \\
\hline 2003 & 33 & 33 & 33 & 50 & 50 & 42 & 67 & 50 & 67 & 67 & 83 & 67 \\
\hline
\end{tabular}

Copyright @ 2002, 2003 Leonard Lardaro, Ph.D. All rights reserved. 